\title{
Efficiency analysis of chilli pepper farming with proliga technology application in Batam City
}

\author{
Khoiru Rizqy Rambe*, Jonri Suhendra Sitompul, Sugeng Widodo, Ahmad Misbah, and \\ Annisa Dhienar Alifia \\ Riau Islands Assessment Institute for Agricultural Technology, Sungai Jang St. No. 38, \\ Tanjungpinang, Riau Islands, Indonesia
}

\begin{abstract}
The existing cultivation pattern of chilli pepper in Riau Islands is unable to fulfilled all market demands. Dissemination of double production (Produksi Lipat Ganda or Proliga) technology was an effort to increase chilli pepper production in Riau Islands. This study aims to analyze the efficiency of chilli pepper farming with Proliga technology application. This research was conducted in Mei 2019 until April 2020 at Maju Mandiri Farmer Group, Setokok Village, Bulang District, Batam City. The primary data obtained from interviews, and the secondary data obtained from related agencies. Data analysis was carried out by calculating costs, revenues, income, and farming efficiency. Based on analysis results, it can be concluded that chilli pepper farming with Proliga technology generates an income of IDR 699,000,000, and the cost incurred in one planting season (12 months) reached IDR 213,193,500. Therefore, the income obtained by farmers is IDR $485,806,500$ / hectare. This chilli pepper farming is considered efficient and profitable for farmers, as indicated by the $\mathrm{R} / \mathrm{C}$ ratio value of 3.27 .
\end{abstract}

\section{Introduction}

Chilli pepper (Capsicum annuum) is considered a strategic commodity in Indonesia as one of the people's basic needs. Consequently, the demand for chilli pepper will increase in line with the increase in the population of Indonesia. The total population of Indonesia in 2020 is 270.203 million with a growth rate of $1.25 \%$. This population growth must be followed by an increase in chilli pepper production, which had reached $1,250,494$ tons in the same year with a growth rate of $2.97 \%$ [1].

Chilli pepper production is carried out throughout Indonesia. The largest producers are West Java, Central Java, North Sumatra, East Java and West Sumatra Province. However, some provinces must rely on supply from other regions to meet the local needs. Riau Islands is one of the provinces that cannot produce enough chilli pepper to meet local demand. Consumption per capita of chilli pepper in households is estimated at 1.905 $\mathrm{kg} /$ capita in 2020, so the total chilli pepper needed to meet the household needs of Riau Islands people reaches 3,932 tonnes [2].Chilli pepper production in Riau Islands reached 4,181 tons from 313 hectares in 2020 [3]. This amount is estimated to be sufficient for

* Corresponding author: khoirurambe7@gmail.com 
household needs, but the added usage by food processing businesses made the production amount insufficient.

The gap between production and market demand indicates an inadequate existing chilli pepper cultivation pattern and technology in Riau Islands.However, land's limited availability in the Riau Islands, which only has about 4 percent of the total geographic area, makes it difficult to increase production with extensification[3]. In addition, the soil conditions in the Riau Islands which are dominated by ultisol soils also do not support the agricultural production process because of the lack of fertile soil, high soil acidity, and inadequate chemical content needed by plants[4].Hence, dissemination of the Double Production (Proliga) technology is introduced to increase chilli pepper production by answering the limitations of land and geographical characteristics in the Riau Islands.

Proliga technology is a chilli pepper cultivation technology package developed by the Agricultural Research and Development Agency in 2018 based on the results of various studies consisting of several key components including the use of superior seeds, seeding, population increase with a zigzag cropping pattern, management of groundwater nutrients and handling of plant pests \{Formatting Citation\}. The application of Proliga technology can raise chilli pepper production by up to $100 \%$ due to the increased plant population and maintenance of 3 main chilli branches instead of a single main branch [7]. Chilli pepper with Proliga Technology application in West Kalimantan yielded $161.2 \%$ higher than the conventional farmer method [8]. In other areas, the application of proliga technology in West Sumatra can result in an increase in production of up to $57.4 \%$ from conventional farmers' methods [5].

Chilli farmers responded positively to the potential adoption of Proliga technology [9]. Therefore, it is hoped that the need for chillies in Riau Islands can be fulfilled through the application of this technology. But the technology dissemination process to farmers requires empirical proof that technology application will positively impact farmers' income. Therefore, this study aims to analyse the efficiency of chilli pepper farming with Proliga technology application.

\section{Research methodology}

This study was conducted from May 2019 to April 2020 at Maju Mandiri Farmer Group, Setokok Village, Bulang District, Batam City Riau Islands.The location selection was determined bypurposive sampling, considering the location was a demonstration plot of Riau Islands Assessment Institute for Agricultural Technology (AIAT).This study only used one farmer as a respondent because that farmer is the only one who has fully implemented proliga technology in the Riau Islands following the dissemination process carried out by Riau Islands AIAT. The results of the application of Proliga technology to this farmer will be used as material for dissemination of this technology to other farmers.

The data collected are primary which wasobtained throughinterviews. Data analysis was carried out by calculating costs, revenues, income, and farming efficiency [10].

1. Costs

Farming costs calculated in this study are all costs incurred by farmers in cultivating chillipepper with Proliga technology application. These costs include variable costs and fixed costs, so they are formulated as follows:

$\mathrm{TC}=$ Total costs

$$
\mathrm{TC}=\mathrm{FC}+\mathrm{VC}
$$

$\mathrm{FC}=$ Fixed costs

$\mathrm{VC}=$ Variable costs 
2. Revenue

Farming revenue is the value sale of chilli pepper obtained by farmers in green and red chillies. Farming revenue is calculated by the following formula:

TR $=$ Total revenue

$$
\mathrm{TR}=\mathrm{P} \times \mathrm{Q}
$$

$\mathrm{P}=$ Price

$\mathrm{Q}=$ Quantity

3. Income

Farming income is the difference between income that farmers get from selling chilli pepper and total costs incurred during the cultivation process. Farming income is calculated by the following formula:

$\pi=$ Income

$$
\pi=\mathrm{TR}-\mathrm{TC}
$$

$\mathrm{TR}=$ Total revenue

$\mathrm{TC}=$ Total costs

4. Efficiency

The method used to determine the efficiency of chilli farming is to calculate the R / Cratio and $\mathrm{MBC}$ ratio. $\mathrm{R} / \mathrm{C}$ ratio calculated following the formula:

$$
\mathrm{R} / \mathrm{C} \text { ratio }=\mathrm{TR} / \mathrm{TC}
$$

The $\mathrm{R} / \mathrm{C}$ ratio results can be categorized into three criteria as follows:

a. $\mathrm{R} / \mathrm{C}$ ratio $>1$, then chilli pepper farming with Proliga technology is efficient.

b. $\mathrm{R} / \mathrm{C}$ ratio $=1$, then chilli farming with Proliga technology is at the break-even point.

c. $\mathrm{R} / \mathrm{C}$ ratio $<1$, then chilli farming with Proliga technology is inefficient.

In addition to assessing efficiency with the $\mathrm{R} / \mathrm{C}$ ratio, the $\mathrm{MBC}$ ratio is also used to determine the increase in farmer income after using Proliga technology. MBC ratio is calculated using the formula [11] :

$$
\mathrm{MBC} \text { ratio }=\frac{\text { Gross receipt of } \mathrm{B}-\text { Gross receipt }}{\text { Total cost of } \mathrm{B}-\text { Total cost of } A}
$$

where, $\mathrm{B}=$ Proliga technology and $\mathrm{A}=$ Conventional method.

If the $\mathrm{MBC}$ ratio $>1$, it can be concluded that the application of Proliga technology is feasible.

\section{Results}

\subsection{Characteristics of respondent}

Individual characteristics can influence the success of the technology dissemination process to increase the efficiency of the agricultural process, both economically and technically. For this reason, data collection on the characteristics of respondent farmers includes age, gender, education level, land area, chilli farming experience, land ownership status and the number of dependents who are considered to affect the dissemination of Proliga technology (Table 1).One of the characteristics considered influencing the farming process is the level 
of education. The level of education affects the allocative efficiency of production inputs in chilli pepper farming[12].Higher education levels will affect farmers' decisions in adopting technology due to rational thinking that the technology will be profitable [13]. The education level of the respondent farmer is Senior High School of Agriculture (SPMA) and is considered capable of adopting Proligachilli technology on his land.

Table 1. Characteristics of respondent

\begin{tabular}{|c|l|c|}
\hline No. & \multicolumn{1}{|c|}{ Characteristics } & Category \\
\hline 1 & Age & 46 \\
\hline 2 & Gender & Male \\
\hline 3 & Education Level & SPMA \\
\hline 4 & Land Area & 1 Ha \\
\hline 5 & Chilli Farming Experience & 1 year \\
\hline 6 & Land Status & Rent \\
\hline 7 & Number of Dependents & 2 People \\
\hline
\end{tabular}

Based on the age category, the respondent is in the productive age category at 46 years. The productive age ranges from 15-64 years, which considered ideal for workers to work optimally in generating income. Other characteristics deemed to affect the farm income level are the area and ownership of agricultural land. Land area affects the level of farm income where farmers with greater control over farmland will have the ability to generate higher income [14]. In this study, total area cultivated by farmers is 1 hectare.

Land tenure status is divided into three categories: owner operator, tenant (cash tenant) and share tenant [15].In this case, the land tenure status cultivated by farmers in the research location is tenancy. Meanwhile, land tenure status has a significant effect on the efficiency of farming costs [16].Differences in land tenure status will determine farmers' access to capital and affect the agricultural production process.

Another characteristic is the number of dependents where the respondent has two children under 17 years old who are still in primary school. Therefore, most of the respondent's farm income is used to meet family needs, even though they still consider investing in the agricultural sector, especially related to land ownership that is still leased.The farmer's experience of farming chilli pepper is only for one year, as the respondent focused on other vegetable crops before converting to chilli. In 2018, chilli pepper farming carried out by farmers using the conventional technique with an area of 0.5 ha, a population of 3,000 chillies with a production of 8.6 tonnes of green chilli and a productivity of $2.3 \mathrm{~kg} /$ plant. Proliga technology dissemination began in 2019 to increase chilli pepper production in Batam City.

Dissemination of agricultural technology needs efforts so that farmers are willing to adopt proliga technology on their land. This adoption process is a systematic process of implementing an innovation that impacts farmers' economy and provides encouragement for the community to accept existing innovations[17].The level of farmer adoption of proliga technology is quite good where farmer was very open and active in receiving, developing, and modifying technology. This can be seen from farmer's decisions to change their production patterns from using conventional methods to production with proliga technology from 2019 to 2021. 


\subsection{Farming costs}

Farming costs are costs incurred by farmers on producing chilli pepper using Proliga technology for one growing season. Farming costs can be categorized into two categories: fixed cost and variable costs. Fixed costs are costs that are not affected by the amount of production. Fixed costs calculated in this study are land rental costs and depreciation of agricultural tools and machinery. The cost of renting 1 hectare per year at the research location is IDR2,000,000, and the depreciation value of the equipment, which is calculated using the straight-line depreciation method, is IDR3,876,000.

Meanwhile, variable costs are costing whose value depends on the volume of chilli pepper production. The variable costs calculated in this study include the cost of seeds. A study has stated that the best seed variety for the application of Proliga technology in dry land is Lado F1 [18]. The chilli pepper variety used in this study is Indrapura variety, a widely adapted chilli pepper in Batam and only cost IDR800,000 (Table 2). In the duration of this study, the farmer achieved more than $20 \mathrm{t} /$ ha potential productivity of chilli pepper. This yieldis much greater than other studies of red chilli pepper varieties such as Tombak variety which has a production potential of $6 \mathrm{t} / \mathrm{ha}$, Tanjung-2 variety with $5.70 \mathrm{t} / \mathrm{ha}$, and Lembang-1 with $4.50 \mathrm{t} / \mathrm{ha}[19]$. It is still higher than the Lotanbar variety, which has a productivity of $15.6 \mathrm{t} / \mathrm{h}$ when cultivated in West Sumatra[20].

Table 2. The costs components of chilli pepper farming

\begin{tabular}{|c|c|c|}
\hline \multirow[b]{2}{*}{ Components } & \multicolumn{2}{|c|}{ Value (IDR) } \\
\hline & $\begin{array}{c}\text { Conventional } \\
\text { Method }\end{array}$ & $\begin{array}{c}\text { Proliga } \\
\text { Technology }\end{array}$ \\
\hline \multicolumn{3}{|l|}{ A. Variable Costs } \\
\hline Seeds & 500.000 & 800,000 \\
\hline Chemical Fertilizer & 17.704 .000 & $18,664,000$ \\
\hline Organic Fertilizer & 18.000 .000 & $18,000,000$ \\
\hline Insectiside & 1.068 .000 & $17,280,000$ \\
\hline Fungicide & 1.104 .000 & $2,770,000$ \\
\hline Mulch & 1.852 .000 & $1,852,000$ \\
\hline Decomposer agent & 2.400 .000 & $2,400,000$ \\
\hline Sticking agents & 80.000 & $2,000,000$ \\
\hline Drip Hose & 4.160 .000 & $4,160,000$ \\
\hline Binder & 470.000 & 940,000 \\
\hline Stake & 3.000 .000 & $5,000,000$ \\
\hline Diesel Fuel & 4.034 .000 & $6,051,500$ \\
\hline Sack & 1.300 .000 & $1,632,000$ \\
\hline Labor Cost & 56.800 .000 & $127,800,000$ \\
\hline Total Variable Cost (VC) & 112.472 .000 & $207,317,500$ \\
\hline \multicolumn{3}{|l|}{ B. Fixed Costs } \\
\hline DepreciationValue of the Equipment & 3.876 .000 & $3,876,000$ \\
\hline Land Lease & 2.000 .000 & $2,000,000$ \\
\hline Total Fixed Costs (FC) & 5.876 .000 & $5,876,000$ \\
\hline Total Costs (TC) & 118.348 .000 & $213,193,500$ \\
\hline
\end{tabular}

Apart from the seed cost, other variable costs include the costs of fertilizers, pesticides, labor, and other production factors. The largest variable cost component in chilli farming with the application of Proliga technology in Karangploso District is the cost of fertilizer which reaches IDR16,500,000 or about $68 \%$ of the total cost[21].Meanwhile, in the Proliga technology application in this study, the largest variable cost component is the labor cost which reaches IDR127,800,000. The total value of variable costs in chilli farming using 
Proliga technology is IDR207,317,500. So that the total cost required during one planting season is IDR213,193,500.

The cost incurred by the farmer when applying the conventional method is IDR112,472,000. This total cost is greater than the cost of cultivating chili in 1 hectare in East Lampung Regency and Kulonprogo Regency which are only IDR46,800,408 and IDR49,917,782, respectively[22,23]. This is due to the greater need for fertilizer to increase soil nutrients in the Riau Islands. The total cost of applying the chili Proliga technology is much higher than the conventional method due to the significant difference in labor use. Farmers use more labor in cultivation with Proliga technology as crop population increases. A significant increase in the number of workers is carried out in the harvesting process.

\subsection{Farming revenue}

Before implementing Proliga technology, the farmer only produced green chili products with a total production of $8,000 \mathrm{~kg}$, making the total farmer's income only at $\mathrm{Rp}$. 180,000,000. After the application of Proliga technology, the chillies were harvested at two stages: green chillies and red chillies (Table 3 ). The resulting green chilli is $5,400 \mathrm{~kg}$, while the red chilli is $15,000 \mathrm{~kg}$. These two products have different selling prices, with green chillies sold at IDR22,500 $/ \mathrm{kg}$ while red chillies are sold at IDR38,500 $/ \mathrm{kg}$. This decision is also in line with a study in Tasikmalaya, where conversion of the harvest stage from green chilli into red chilli raised the farmers' revenue by $77.6 \%$ and income up to $57,6 \%$ [24]. Thus, the total revenue obtained by farmers is IDR699,000,000.This amount is far greater than the total revenue of chilli farming in Jember Regency, which reached IDR108,873,952, and in Garut Regency, which was only IDR85,750,755.62[25,26].

Table 3. Total revenue of chilli pepper farming

\begin{tabular}{|c|c|c|c|c|c|}
\hline Method & Products & Unit & Volume & Price/Unit (IDR) & Value (IDR) \\
\hline Conventional & Green Chilli & $\mathrm{Kg}$ & 8.000 & 22.500 & $\mathbf{1 8 0 . 0 0 0 . 0 0 0}$ \\
\hline \multirow{3}{*}{$\begin{array}{c}\text { Proliga } \\
\text { Technology }\end{array}$} & Green Chilli & $\mathrm{Kg}$ & 5,400 & 22,500 & $121,500,000$ \\
\cline { 2 - 6 } & Red Chilli & $\mathrm{Kg}$ & 15,000 & 38,500 & $577,500,000$ \\
\cline { 2 - 5 } & \multicolumn{5}{|c|}{ Total proliga technology } \\
\hline
\end{tabular}

\subsection{Income and farming efficiency}

Farming income is the difference between revenue and costs incurred or the total value of revenue deducted from the total production costs in the farming process[14]. Therefore, to maximize the income of chilli farming received by farmers, it can be done by reducing expenses or production costs while still increasing revenue. The application of Proliga technology is an effort to increase farmers' acceptance because it is considered capable of increasing the number of chillies harvested significantly. The income earned by chilli farmers using the Proliga technology application is IDR485,806,500, but the income while still using conventional technology is only IDR61,652,000 (Table 4). This Proliga income is remarkably higher than conventional chilli farming in Sleman Regency which only generates income for the average farmer of IDR79,982,855 per hectare and chilli farming in Sidenreng Rappang Regency which generates an income of IDR 46,336,000 per hectare[27,28]. 
Table 4. Analysis of income and efficiency of chilli pepper farming

\begin{tabular}{|c|c|c|}
\hline \multirow{2}{*}{ Components } & \multicolumn{2}{|c|}{ Value } \\
\cline { 2 - 3 } & Conventional method & Proliga technology \\
\hline Revenue & IDR 180.000 .000 & IDR $699,000,000$ \\
\hline Costs & IDR 118.348 .000 & IDR 213,193,500 \\
\hline Income & IDR 61.652 .000 & IDR 485,806,500 \\
\hline R/C Ratio & 1.52 & 3.27 \\
\hline MBC Ratio & 0 & 5.47 \\
\hline
\end{tabular}

Based on the analysis of costs and revenues that have been carried out, the efficiency of chillipepper farming with the application of Proliga technology can be determined by calculating the $\mathrm{R} / \mathrm{C}$ ratio value. The result shows the $\mathrm{R} / \mathrm{C}$ value of this farming ratio is 3.27 , indicating that chilli farming with Proliga technology is an efficient and profitable agricultural practice for farmers. This result is greater than the $\mathrm{R} / \mathrm{C}$ ratio value in the application of Proliga technology in West Sumatra which only reached 1.51[5]. However, the application of Proliga technology in North Sumatra only resulted in a B/C ratio of 0.13 because the average productivity of farmers was only $4.2 \mathrm{t} / \mathrm{ha}$ and the selling price of farmers was only IDR25,000 [6].

The $\mathrm{R} / \mathrm{C}$ value of this study is greater than conventional chilli farming in the highlands of Bengkulu and in North Sumatera, which only has an $\mathrm{R} / \mathrm{C}$ ratio of 1.4 and 1.52 respectively [29,30]. Chilli pepper cultivation without the application of Proliga technology in other areas such as Kediri Regency, Garut Regency, and Tanggamus Regency also has an R/C ratio value that is smaller than this study with $\mathrm{R} / \mathrm{C}$ ratio values of $1.77,1.96$, and 3.26 respectively. [31-33].However, this $\mathrm{R} / \mathrm{C}$ ratio value is smaller than chilli farming in Cirociroe Village, Sidenreng Rappang Regency, which has an R/C ratio of 9.48 and chilli farming in Antapan Village, Tabanan Regency, which has an R/C ratio of 20.4[28,34].

Although chilli pepper cultivation using conventional methods is still profitable with an $\mathrm{R} / \mathrm{C}$ value of 1.52 , the application of this chili Proliga technology clearly shows a significant increase in farmer income. This was indicated by the MBC ratio value of 5.47. The MBC value of this ratio means that every additional IDR1 spent by farmers in switching from conventional methods to cultivation with Proliga technology, results in an additional income of IDR 5.47.

\section{Conclusion}

According to the analysis, it can be concluded that chilli farming with the Proliga technology application generates revenue of IDR 699,000,000 and the costs incurred in one planting season reach IDR 213,193,500. Thus, the income obtained by farmers is IDR $485,806,500$, - from farming chilli using the Proliga technology application, covering an area of 1 hectare. This chilli farming is considered efficient and profitable for farmers as indicated by the $\mathrm{R} / \mathrm{C}$ ratio value of 3.27 and $\mathrm{MBC}$ ratio value of 5.47.

\section{References}

1. BPS-Statistics Indonesia, Statistik Indonesia 2021 (BPS-Statistics Indonesia, Jakarta, 2021).

2. Kementerian Pertanian, Buletin Konsumsi Pangan (Jakarta, 2019).

3. BPS-Statistics of Kepulauan Riau Province, Provinsi Kepulauan Riau Dalam Angka 2021 (BPS-Statistics of Kepulauan Riau Province, Tanjungpinang, 2021).

4. M. J. Siregar and A. Nugroho, J. Serambi Eng. 6(3) (2021). 
5. Atman, C. Indrawanto, Yuniarti, Y. A. Dewi, and F. Hendrawan, in IOP Conf. Ser. Earth Environ. Sci. (2021)

6. S. Tobing, T. Sipahutar, T. Simatupang, M. Girsang, and Nurfaida, Int. Conf. Food Secur. Sustain. Agric. Trop. 807 (2021).

7. S. Bardono, Technology-Indonesia.Com (2018)

8. N. F. Devy, Hardiyanto, J. A. Syah, R. Setyani, and B. K. Udiarto, IOP Conf. Ser. Earth Environ. Sci. 752, (2021).

9. N. Puspitasari, N. Hardiyanto, W. Adiyoga, and A. M. Kiloes, J. Hortik. 29, 257 (2020).

10. M. T. Sundari, SEPA. 7, (2011).

11. N. Prasetiaswati, Y. Prayogo, M. S. Y. I. Bayu, S. Sumartini, Y. Widodo, S. W. Indiati, F. Rozy, and M. J. Mejaya, J. Agric. Sci. 13, 113 (2021).

12. J. Asravor, E. E. Onumah, and Y. B. Osei-asare, J. Agricutural Ext. Rural Dev. 8, 99 (2016)

13. Risna, S. R. Heni, and I. Andi Baso Lompengeng, in Pros. Semin. Nas. Kesiapan Sumber Daya Pertan. Dan Inov. Spesifik Lokasi Memasuki Era Ind. 4.0 (2018), pp. 436-443

14. E. M. Jannah, Inform. Pertan. 21, 95 (2016)

15. B. Mudakir, J. Din. Ekon. Pembang. 1, (2012)

16. L. Rahayu and D. Febriani, in E3S Web Conf. (2021), pp. 1-11

17. C. R. Adawiyah, Forum Penelit. Agro Ekon. 35, 59 (2018)

18. A. Y. Naibaho, M. Heviyanti, and R. Maharany, J. Agroqua 19, 159 (2021)

19. M. Taufik, J. Penelit. Dan Pengemb. Pertan. 30, 66 (2016)

20. D. Evaliza, N. E. Putri, and H. Fauza, Int. J. Adv. Sci. Eng. Inf. Technol. 5, (2015)

21. E. N. Julitasari and Suwarta, in Conf. Innov. Appl. Sci. Technol. (2020), pp. 285-292

22. D. S. Maharti, J. Penelit. Agrisamudra 6, 104 (2019)

23. E. Istiyanti, U. Khasanah, and A. Anjarwati, Agrar. J. Agribus. Rural Dev. Res. 1(6) (2015)

24. D. Djuliansah, Mimb. AGRIBISNIS J. Pemikir. Masy. Ilm. Berwawasan Agribisnis 1 (2018)

25. N. Ni'mah, Y. Hariyati, and T. Agustina, Analysis of price and cost efficiensy of red chili (Capsium Annuum L) farming in Wuluhan Subdistrict Jember District (2017)

26. Z. Saidah, H. Harianto, S. Hartoyo, and R. W. Asmarantaka, J. Manaj. Dan Agribisnis 16, 66 (2019)

27. J. Saputro and I. Kruniasih, Agros 15, 111 (2013)

28. R. Rasidin, Y. Yusriadi, and R. Rahman, J. Pendidik. Teknol. Pertan. 4, 84 (2018)

29. R. Hartono and H. B. Astuti, Balai Pengkaj. Teknol. Pertan. Bengkulu (2015)

30. A. A. Cahya and R. H. Br Bangun, Agricore J. Agribisnis Dan Sos. Ekon. Pertan. Unpad 5, 49 (2020)

31. R. Indrasti, J. Rawung, N. Sudolar, K. Andri, Sahram, and S. Tan, IOP Conf. Ser. Earth Environ. Sci. 807, 9 (2021)

32. N. Mala, F. E. Prasmatiwi, and W. D. Sayekti, J. Ilmu Ilmu Agribisnis J. Agribus. Sci. 9, 62 (2021)

33. Z. Saidah, Harianto, S. Hartoyo, and R. W. Asmarantaka, IOP Conf. Ser. Earth Environ. Sci. 466, (2020)

34. H. G. Baru, D. Tariningsih, and I. M. Tamba, J. Pertan. Berbas. Keseimbangan Ekosist. 8, (2013) 